\title{
Nerve Growth Factor Rapidly Prolongs the Action Potential of Mature Sensory Ganglion Neurons in Culture, and This Effect Requires Activation of Gs-coupled Excitatory $\kappa$-Opioid Receptors on These Cells
}

\author{
Ke-Fei Shen ${ }^{1}$ and Stanley M. Crain ${ }^{1.2}$ \\ Departments of ${ }^{1}$ Neuroscience and ${ }^{2}$ Physiology/Biophysics, Albert Einstein College of Medicine, Yeshiva University, \\ Bronx, New York 10461
}

\begin{abstract}
Application of low concentrations ( $\mathrm{pM-nM)}$ of NGF to mouse dorsal root ganglion (DRG)-spinal cord explants in long-term organotypic cultures rapidly prolongs the duration of the $\mathrm{Ca}^{2+}$-dependent component of the action potential (APD) in a major subset of DRG neurons that were previously shown to have characteristic responsiveness to exogenous opioids. These NGF-elicited excitatory modulating effects are blocked by pretreatment of the DRG neurons with monoclonal antibodies to rodent NGF receptors. NGF-induced APD prolongation is also prevented by the opioid receptor antagonist naloxone and the specific $\kappa$-opioid antagonist nor-binaltorphimine (but not by specific $\mu$ - and $\delta$-opioid antagonists). The results suggest that NGF stimulates the release of endogenous opioids (e.g., dynorphin) from DRG neurons and that prolongation of the APD occurs secondarily by activation of excitatory $\boldsymbol{\kappa}$-opioid receptor functions on these same or nearby cells. NGF-induced release of small quantities of opioids by DRG neurons would be expected to prolong the APD in view of the remarkable sensitivity of these neurons to the excitatory effects of extremely low (fm-nM) concentrations of exogenous opioid agonists. NGF-induced APD prolongation is blocked by the same cholera toxin A or B subunit treatments previously shown to block Gs coupling and GM1 ganglioside regulation of excitatory opioid receptors, respectively. These in vitro studies suggest that excitatory opioid receptor-mediated functions may play a role in mediating some types of rapid NGF-induced hyperalgesic and other physiologic effects on the nervous system.
\end{abstract}

[Key words: dorsal root ganglion neuron, $\mathrm{Ca}^{2+}$-dependent component of action potential, anti-NGF receptor antibody, specific opioid receptor antagonists, cholera toxin-sensitive excitatory opioid receptors]

This laboratory previously showed that long-term treatment with NGF shortens the duration of the $\mathrm{Ca}^{2+}$-dependent component of the action potential (APD) of mature mouse dorsal

\footnotetext{
Reccived Aug. 19, 1993; revised Mar. 11, 1994; accepted Mar. 24, 1994.

We thank Dr. John A. Kessler for helpful comments on the initial draft of the manuscript. The DRG-cord cultures were prepared by Peter Vanamee in tissue culture facilities kindly provided by Dr. Murray B. Bornstein. This work was supported by Research Grant DA-02031 to S.M.C.

Correspondence should be addressed to Stanley M. Crain, Ph.D., 1300 Morris Park Avenue, Bronx, NY 10461.

Copyright (C) 1994 Society for Neuroscience $0270-6474 / 94 / 145570-10 \$ 05.00 / 0$
}

root ganglion (DRG) neurons in culture when applied at concentrations of 0.3-30 nM for $>2 \mathrm{~d}$ (Chalazonitis et al., 1987). Conversely, application of anti-NGF antiserum to chronic NGFtreated DRG cells prolonged the APD to control values after $>1 \mathrm{~d}$. In contrast to these slowly developing bioelectric effects, NGF has been shown to elicit much more rapid biochemical and structural changes in nerve cells (Greene and Shooter, 1980; Greene, 1984; Levi and Alema, 1991). For example, application of $\mathrm{nM}$ NGF to $\mathrm{PCl} 2$ cells results in increased cytosolic $\mathrm{Ca}^{2+}$ concentration within minutes, due to enhanced $\mathrm{Ca}^{2+}$ influx as well as release from internal stores (Lazarovici et al., 1989). Furthermore, nanomolar NGF increases the $\mathrm{Ca}^{2+}$-dependent release of dopamine and norepinephrine from $\mathrm{PC} 12$ cells within a few minutes (Nikodijevic et al., 1990) and the release of histamine from mast cells within minutes in vitro in the presence of lysophosphatidyl serine (Bruni et al., 1982; Sugiyama et al., 1985; Mazurek et al., 1986). In addition, NGF enhancement of endogenously released adenosine effects on PC12 cells (Race and Wagner, 1985) may account for previous reports that NGF rapidly stimulates cAMP levels in PC12 and other types of neurons (Nikodijevic et al., 1975; Schubert et al,, 1978; Skaper et al., 1979).

In a recent review, Levi-Montalcini et al. (1990) reported that "following intravenous NGF administration, adult mice show a hyperalgesic response in a hot-plate test." This observation led us to test the hypothesis that NGF-induced hyperalgesia may be mediated by activation of NGF receptors on nociceptive types of DRG neurons that results in a rapid excitatory effect on these sensory cells. We previously showed that low concentrations of $\mu-, \delta$, , or $\kappa$-opioid agonists $(<n M)$ evoke excitatory APD-prolonging effects on many mouse DRG neurons in culture (Shen et al., 1989; Crain and Shen, 1990) by activating opioid receptors that are coupled via cholera toxin-sensitive Gs regulatory protein (Shen and Crain, 1990a, 1994) to adenylate cyclase/cAMP/protein kinase A-dependent ionic conductances (Chen et al., 1988; Fan et al., 1991; Cruciani et al., 1993; Makman et al., 1994). This is in contrast to the inhibitory shortening of the APD in DRG neurons elicited by higher $(\mu \mathrm{M})$ concentrations of opioids that is mediated by opioid receptors that are linked via pertussis toxin-sensitive $\mathrm{Gi} / \mathrm{Go}$ regulatory proteins (Shen and Crain, 1989; Gross et al., 1990) to other second messenger systems or directly to specific ion channels (Miyake et al., 1989). Opioid-induced APD shortening in DRG perikarya has generally been considered to be a useful model of opioid analgesia mediated by inhibition of $\mathrm{Ca}^{2+}$ influx and transmitter 
release (e.g., substance P) at presynaptic terminals of primary afferent nociceptive neurons bearing inhibitory opioid receptors (Mudge et al., 1979; Werz and Macdonald, 1983; North, 1986; Shen and Crain, 1989; Crain and Shen, 1990). Similarly, we have interpreted the delayed repolarization associated with APD prolongation that can often be evoked in the same DRG neuron perikarya by lower opioid concentrations as evidence of excitatory opioid receptor-mediated effects on these neurons. If similar increases in $\mathrm{Ca}^{2+}$ influx and transmitter release (e.g., substance P: Suarez-Roca and Maixner, 1993) also occur at the terminals of these DRG neurons, they "may mediate some of the paradoxical hyperalgesic and aversive side-effects of opioids in the central and peripheral nervous system" (Shen and Crain, 1989; see review by Crain and Shen, 1990).

Application of low concentrations of NGF (pM-nM) to the same population of cultured DRG neurons that are responsive to exogenous opioids did, in fact, prolong the APD within a few minutes via activation of receptors that could be blocked by monoclonal antibodies to rodent NGF receptors. Surprisingly, NGF-induced prolongation of the APD was also prevented by the opioid receptor antagonist, naloxone, the specific $\kappa$-opioid receptor antagonist nor-binaltorphimine, as well as by other agents that block opioid-induced excitatory effects on DRG neurons (e.g., cholera toxin A and B subunits: Shen and Crain, $1990 \mathrm{a}, \mathrm{b})$. These and related data suggest that NGF may stimulate the release of endogenous opioids (e.g., dynorphin) from DRG neurons that can then activate high-affinity excitatory $\kappa$-opioid receptors on these cells, thereby resulting in APD prolongation.

A preliminary report of this study has been published (Shen and Crain, 1993).

\section{Materials and Methods}

Tissue culture. Organotypic DRG-cord explants were prepared by dissecting transverse sections of spinal cord with attached DRGs from 13d-old fetal mice (CD-1, Charles River). The explants were grown on collagen-coated coverslips in Maximow slide chambers and fed with Eagle's minimal essential medium supplemented with $25 \%$ fetal bovine serum, $10 \%$ chick embryo extract, $2 \mathrm{~mm}$ glutamine, $0.6 \%$ glucose and $10 \mathrm{~mm}$ HEPES buffer. During the first week in vitro the medium was supplemented with NGF (7S) at a concentration of $5 \mathrm{nM}(\sim 50 \mathrm{U} / \mathrm{ml})$ to enhance survival and growth of the fetal mouse DRG neurons (Crain and Peterson, 1974; Crain, 1976; Chalazonitis and Crain, 1986). Halfmaximal stimulation of initial neuritic outgrowth from these fetal DRG explants required about $0.1 \mathrm{nM} \mathrm{NGF}$, but $>90 \%$ of the DRG neurons degenerated within the first few days in vitro unless much higher concentrations of NGF were maintained during the first week after explantation (Crain and Peterson, 1974, 1984). Cultures were fed twice weekly and maintained at $34^{\circ} \mathrm{C}$ for electrophysiologic study after 3-7 weeks in vitro. For chronic treatment with $\mathrm{K} 252 \mathrm{a}(200 \mathrm{nM})$, the drug was added to the nutrient medium of some of the cultures, beginning at 4 weeks in vitro, for 3-6 d.

Electrophysiology. The culture coverslip was transferred to a small recording chamber containing about $1 \mathrm{ml}$ of Hanks' balanced salt solution (BSS) supplemented with $4 \mathrm{mM} \mathrm{Ca}^{2+}$ and $5 \mathrm{mM} \mathrm{Ba}^{2+}$ (i.e., $\mathrm{Ca} /$ $\mathrm{Ba}$ BSS). Addition of $\mathrm{Ba}^{2+}$ and high $\mathrm{Ca}^{2+}$ enhanced inward $\mathrm{Ca}^{2+}$ current, and $\mathrm{Ba}^{2+}$ suppressed delayed rectifying $\mathrm{K}^{+}$current, thereby prolonging the $\mathrm{Ca}^{2+}$-dependent component of the action potential duration (APD) and providing a prominent baseline response for pharmacologic tests (Mudge et al., 1979; Werz and Macdonald, 1983; Chalazonitis and Crain, 1986; Chalazonitis et al., 1987; Shen and Crain, 1989). The presence of $5 \mathrm{~mm} \mathrm{Ba}^{2+}$ greatly enhanced the sensitivity of the DRG neurons to the excitatory APD-prolonging effects of opioids (Shen and Crain, 1989; Crain and Shen, 1990). HEPES (10 mM; pH 7.3) was used to replace the usual bicarbonate and phosphate buffers to prevent $\mathrm{Ba}^{2+}$ and $\mathrm{Ca}^{2+}$ precipitation. Intracellular recordings were made from DRG perikarya selected at random within each ganglion. The micropipettes were filled with $3 \mathrm{M} \mathrm{KCl}$ (resistance $\sim 80-120 \mathrm{M} \Omega$ ) and were connected via a chloridized silver wire to a neutralized input-capacity preamplifier (Axoclamp 2A) for current-clamp recording. After impalement of a DRG neuron, brief $(2 \mathrm{msec})$ depolarizing current pulses were applied via the recording electrode to evoke action potentials (APs), at a frequency of $0.1 \mathrm{~Hz}$. Recordings of the membrane resting potential (RP) and AP were stored on a floppy disk using the pCLAMP program (Axon Instruments) in a microcomputer (IBM AT-compatible).

Drugs were applied by bath perfusion with a manually operated pushpull syringe system at a rate of $2-3 \mathrm{ml} / \mathrm{min}$. Perfusion of NGF or other test agents was begun after the AP and RP of the neuron reached a stable condition during $>4$ min pretest periods in control $\mathrm{Ca} / \mathrm{Ba}$ BSS. Tests were made on cells with RPs $>60 \mathrm{mV}$. NGF-mediated changes in the APD were considered significant if the APD alteration was $>10 \%$ of the control value. The APD was measured as the time between the peak of the APD and the inflection point on the repolarizing phase. Application of electric stimuli via a bridge-circuit precluded quantitation of possible NGF effects on the rate of rise of the AP. Since the $A P D$ varies with membrane RP, we generally applied a holding current manually to maintain the initially recorded RP at a slightly hyperpolarized level $(\sim-70 \mathrm{mV})$ during the pharmacologic tests on each DRG neuron. This precluded systematic study of possible NGF-induced alterations in postspike hyperpolarization.

The following drugs (and their sources) were used in this study: NGF $7 \mathrm{~S}$ (Collaborative Research); NGF 2.5S and rat anti-NGF-receptor (192. IgG, Boehringer Mannheim); K-252a (Calbiochem); adenosine deaminase, dynorphin $\mathrm{A}(1-13)$, and $\mathrm{D}-\mathrm{Ala}^{2}, \mathrm{D}-\mathrm{Leu}^{5}$-enkephalin (DADLE) (Sigma); cholera toxin A subunit and B subunit (List); purified GM1 ganglioside (gift from Fidia); naloxone (Endo); (+)naloxone (NIDA); nor-binaltorphimine $\mathrm{HCl}$, naltrindole $\mathrm{HCl}, \beta$-funaltrexamine $\mathrm{HCl}(\mathrm{Re}$ search Biochemical). Stock solutions were prepared in distilled water $(\sim 1 \mathrm{mM})$ and stored frozen; $7 \mathrm{~S}$ and 2.5S NGF were prepared in Eagle's minimal essential medium supplemented with $25 \%$ fetal bovine serum at concentrations of $100 \mu \mathrm{g} / \mathrm{ml}$ and aliquots were stored at $-70^{\circ} \mathrm{C}$ and not refrozen after thawing. Cholera toxins were stored at $4^{\circ} \mathrm{C}$. Cholera toxin-B subunit was heated to $56^{\circ} \mathrm{C}$ for $30 \mathrm{~min}$ to inactivate possible contamination with cholera toxin-A subunit (Shen and Crain, 1990b). Stock solutions were diluted with the bath solution to desired test concentrations, discarding pipette tips after each successive 10-100-fold dilution step to ensure accuracy of extremely low (pM-fM) concentrations (Shen et al., 1991; Crain and Shen, 1992). In preparing test solutions of $7 \mathrm{~S}$ and $2.5 \mathrm{~S} \mathrm{NGF}$, the molecular weights of these preparations were considered to be 130,000 and 25,000 , respectively.

Data analysis for determining significant differences was carried out with paired $t$ test.

\section{Results}

In our previous studies, treatment of mouse DRG neurons with NGF 7S (0.3-30 nM) for $>2 \mathrm{~d}$ resulted in a marked shortening $(\sim 30-60 \%)$ of the APD of these cells (Chalazonitis et al., 1987), whereas no changes in the APD were observed in tests made after exposure to NGF for 3-4 hr. In the present study, electrophysiologic tests were carried out on similar long-term cultures of DRG-cord explants to determine if NGF could elicit much more rapid alterations in the APD of DRG neurons such as occur within minutes after acute application of opioids, monoamines, and other neurotransmitters (Mudge et al., 1979; Werz and Macdonald, 1983; Chalazonitis and Crain, 1986; Shen and Crain, 1989).

$N G F$ rapidly prolongs the APD of opioid-sensitive DRG neurons. Intracellular recordings were made from small- and medium-sized DRG neuron perikarya $(\sim 10-30 \mu \mathrm{m}$ in diameter) that generate relatively long APDs ( $>3 \mathrm{msec}$ in $\mathrm{Ca}^{2+} / \mathrm{Ba}^{2+} \mathrm{BSS}$ ) and that show characteristic responsiveness to opioid agonists (Shen and Crain, 1989; Crain and Shen, 1990; see introductory remarks). Acute application of selective inhibitory opioid receptor agonists (e.g., etorphine) to these DRG neurons shorten the APD in $80-90 \%$ of the cells tested, whereas low concentrations of bimodally acting (excitatory/inhibitory) opioids (e.g., morphine, dynorphin, enkephalins) prolong the APD in these same cells (Shen and Crain, 1994). Relatively small numbers of 

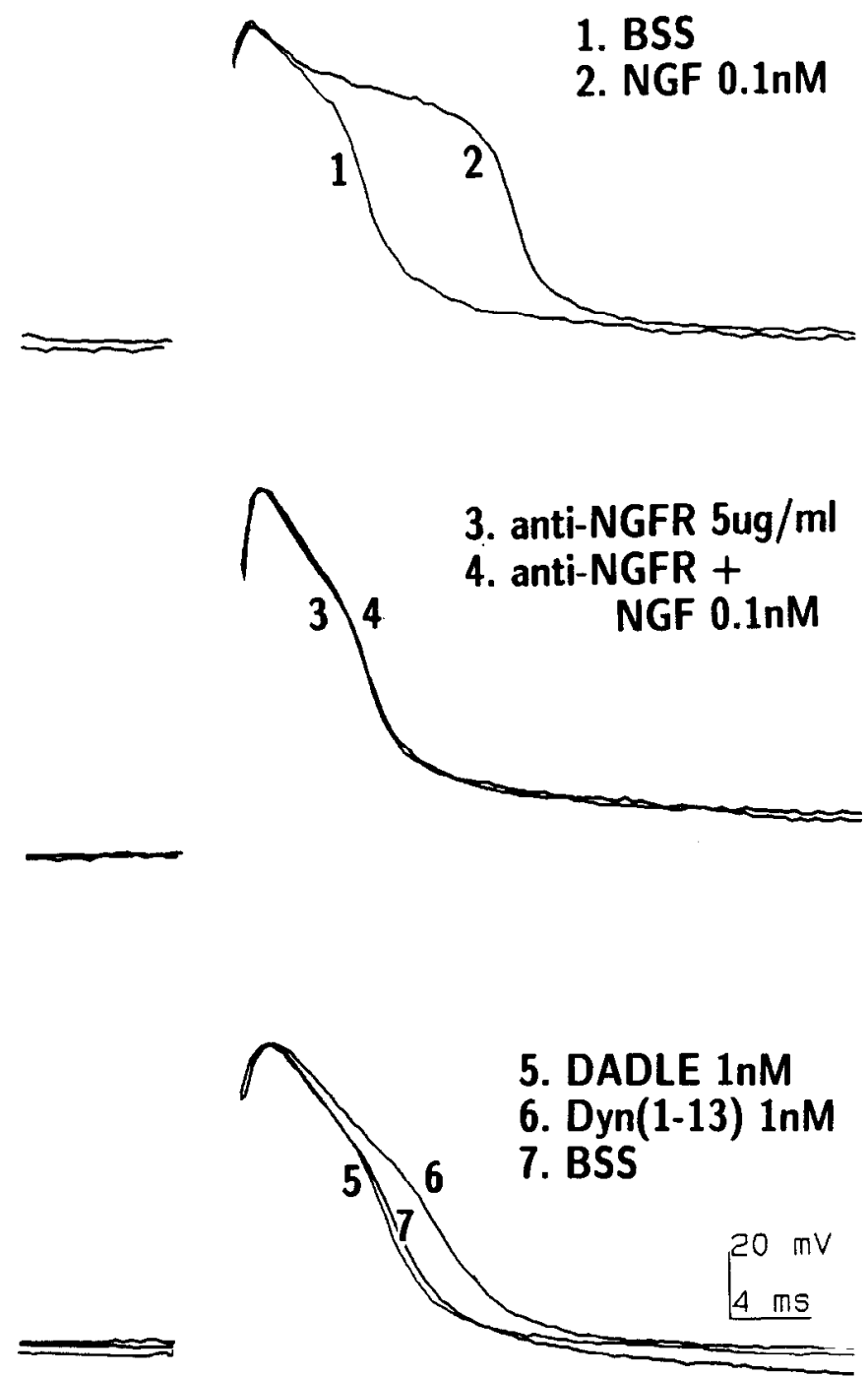

Figure 1. NGF-evoked prolongation of the action potential duration (APD) of a cultured DRG neuron is blocked by pretreatment with antibodies to NGF receptors (anti-NGFR), whereas exogenous opioidevoked APD prolongation can still occur. 1, AP generated by a DRG neuron in balanced salt solution containing $5 \mathrm{mM} \mathrm{Ca}^{2+}$ and $5 \mathrm{mM} \mathrm{Ba}^{2+}$ $(B S S)$ in response to brief $(2 \mathrm{msec})$ depolarizing current pulse (same 2 msec stimulus used in all subsequent records). 2, APD is prolonged within $5 \mathrm{~min}$ after bath application of $0.1 \mathrm{nM}$ NGF 7S. 3, After BSS rinse for $10 \mathrm{~min}$ and treatment with anti-NGFR (192-IgG, $5 \mu \mathrm{g} / \mathrm{ml}$ ), APD returns to control value then stably maintained $(\sim 15 \mathrm{~min})$ prior to additional tests. 4, Application of NGF $(0.1 \mathrm{nM})$ in the presence of anti-NGFR is no longer effective in prolonging the APD ( $5 \mathrm{~min}$ test). 5 and 6 , The same neuron shows no APD alteration during application of $1 \mathrm{nM}$ DADLE, but the APD is significantly prolonged by $1 \mathrm{nM}$ dynorphin A(1-13). 7, After BSS rinse, APD shortens again. (Control tests indicated that anti-NGFR remains effective in blocking NGF-induced APD prolongation for $>1 \mathrm{hr}$ after BSS rinse; see text.) Note that records in this and the subsequent figures are from DRG neurons in DRGspinal cord explants tested at 3-5 weeks in vitro. All acute tests were monitored for $5 \mathrm{~min}$ periods.

large DRG neurons ( $\sim 30-50 \mu \mathrm{m}$ in diameter) survive in our DRG-cord explants $(\sim 10-20 \%)$ and they show much shorter APDs ( 1-2 msec), with no clear-cut inflection or "hump" on the falling phase of the spike (see Discussion). The APD of these large DRG neurons was not altered by exogenous opioids in our previous studies, or by NGF in the present study.

In contrast to the APD shortening observed after chronic
NGF treatment of DRG neurons, acute application of similar and even much lower concentrations of NGF (7S or $2.5 \mathrm{~S})$ often elicited unexpected prolongation of the APD within a few minutes (Fig. $1_{1,2}, 2 A_{1,2}$ ). Both 7S and 2.5S NGF were effective at low concentrations in prolonging the APD of many DRG neurons by $20-120 \%$ (mean $68 \pm 6 \%, n=99$ ): in $78 \%$ of the cells tested at $0.1-1$ pM $(n=18 ; p<0.001)$; in $88 \%$ of the cells tested at $10-100$ pм $(n=58 ; p<0.001)$; in $93 \%$ of the cells tested at $1-10 \mathrm{nM}(n=41 ; p<0.001)$. No significant evidence of NGFinduced APD shortening, nor alterations of the resting potential, was observed during these acute tests. The magnitude of the APD prolongation elicited by acute application of NGF did not show significant dose-dependent increases when tested at concentrations from $1 \mathrm{pM}$ to $10 \mathrm{nM}$. The $2.5 \mathrm{~S}$ form of NGF elicited similar effects on the APD as observed with the 7S form, except that the APD prolongation during sustained exposure to NGF2.5S tended to attenuate more rapidly, often within $5 \mathrm{~min}$. After washout of either form of NGF the APD generally returned to control values within 5-10 $\mathrm{min}$, but in some cases recovery was much slower ( $>15 \mathrm{~min}$, e.g., $A_{3}$ vs $A_{1}$ in Fig. 2).

These excitatory effects of NGF on DRG neurons were mediated by activation of NGF receptors since they were blocked after pretreatment of the cells with monoclonal antibodies to rodent NGF receptors (anti-NGFR; 192-IgG), in five of five cells treated with $5 \mu \mathrm{g} / \mathrm{ml}$ anti-NGFR and in two of three cells with $50 \mathrm{ng} / \mathrm{ml}$ anti-NGFR (Fig. $1_{3,4}$ ). Interestingly, the antiNGFR used in the present study is directed against the "lowaffinity" p75 NGF receptor (Chandler et al., 1984; see Discussion).

Specific к-opioid receptor antagonists block $N G F$-induced $A P D$ prolongation. Since extremely low ( $\mathrm{fM}-\mathrm{nM}$ ) concentrations of bimodally acting opioids can rapidly prolong the APD of these nociceptive-like DRG neurons (Shen et al., 1991; Crain and Shen, 1992a), tests were carried out to evaluate possible opioid mediation of the NGF-induced APD prolongation. To our surprise, pretreatment of DRG neurons with naloxone (10 $\mathrm{nM})$ prevented NGF-induced prolongation of the APD in 15 of 18 cells (Fig. $2 A_{3,4}$ ), whereas the inactive enantiomer ( + )naloxone (10 nM) was ineffective in blocking NGF-induced APD prolongation of these cells $(n=4)$. The specificity of our anti-NGF receptor antibody preparation was controlled by tests showing that anti-NGFR $(5 \mu \mathrm{g} / \mathrm{ml})$ did not block exogenous opioid-induced APD prolongation (tested with $1 \mathrm{nM}$ dynorphin $\mathrm{A}(1-13)$ or DADLE; four of six cells; see also Fig. $1_{5-7}$ ). These results raise the possibility that NGF might stimulate the release of endogenous opioid from DRG neurons that in turn could activate excitatory opioid receptors (Crain and Shen, 1990) on the perikaryal surface of the same cells, thereby resulting in APD prolongation. This hypothesis was strengthened by additional tests with antagonists of specific $\mu-, \delta$-, and $\kappa$-opioid receptors. Nor-binaltorphimine (10 $\mathrm{nm}$ ), a specific $\kappa$-antagonist, blocked NGF-induced APD prolongation in 10 of 12 DRG neurons (Fig. $\left.2 B_{5,6}\right)$, whereas the $\mu$ - and $\delta$-antagonists $\beta$-funaltrexamine and naltrindole $(10-100 \mathrm{nM})$ were ineffective $(n=12)$ (Fig. $\left.2 B_{1-4}\right)$. These pharmacologic tests suggest that NGF may prolong the APD of DRG neurons by stimulating release of specific endogenous opioids that could subsequently activate high-affinity excitatory $k$-opioid receptors on these cells. The presence of functional excitatory $\kappa$-opioid reccptors on DRG neurons showing NGF-induced APD prolongation was also demonstrated by the APD-prolonging effects evoked in the same cells after washout of NGF and application of exogenous dynorphin (e.g., Fig. $1_{5-7}$ ). 
A
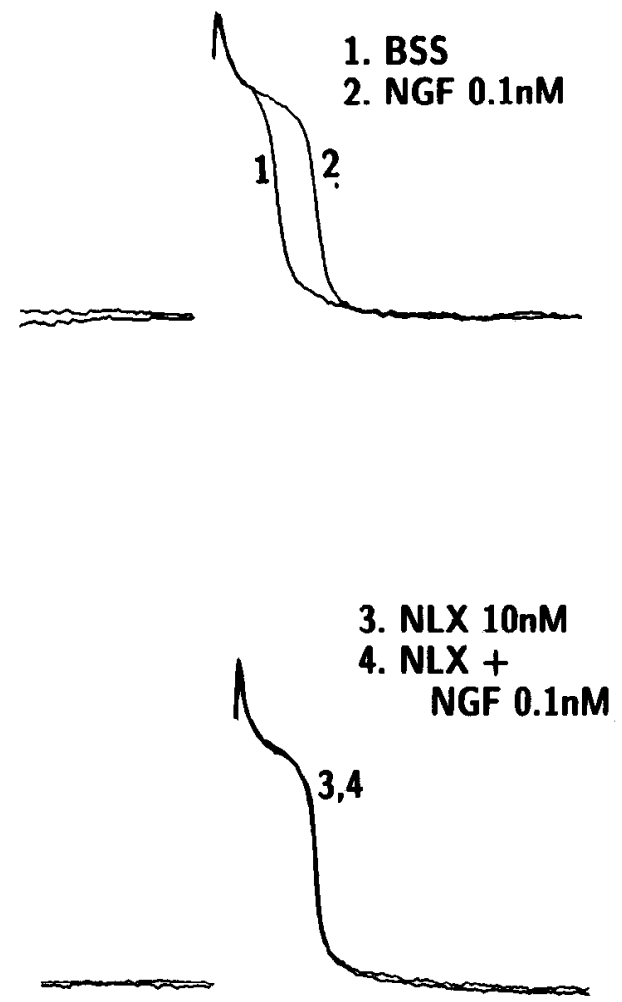

B

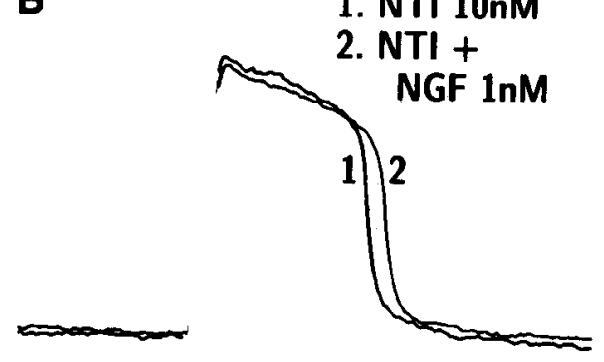

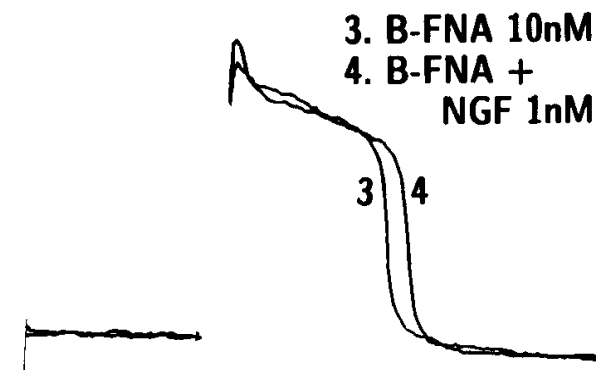

בתח

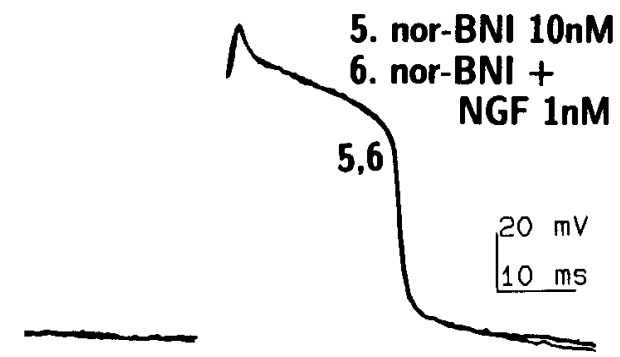

Figure 2. Pretreatment of DRG neurons with the opioid receptor antagonist naloxone $(N L X)$ or the specific $\kappa$-opioid receptor antagonist nor-binaltorphimine (nor-BNI) blocks NGFinduced APD prolongation, whereas $\mu$ and $\delta$-opioid antagonists are ineffective. $A_{l, 2}$, APD of a DRG neuron is prolonged by application of $0.1 \mathrm{nM}$ NGF (as in Fig. $1_{1,2}$ ). $A_{3}$, After BSS rinse and introduction of $10 \mathrm{~nm}$ NLX, APD shortens and is then stably maintained ( $\sim 15 \mathrm{~min}$ ) prior to additional tests. $A_{4}$ Application of $0.1 \mathrm{nM}$ NGF in the presence of NLX is no longer effective in prolonging the APD. $B_{t, 2}$, In contrast, application of NGF (1 nM) to another DRG neuron in the presence of the $\delta$-opioid antagonist, naltrindole $(N T I ; 10$

nM, 7 min pretreatment), is still effective in prolonging the APD. $B_{3.4}$, The $\mu$-opioid antagonist $\mathrm{B}$-funaltrexamine (B-FNA; $10 \mathrm{nM}, 10 \mathrm{~min}$ pretreatment) is also ineffective in blocking the NGFinduced APD prolongation of this neuron. $B_{5,6}$, However, in the presence of the $\kappa$-opioid antagonist nor-BNI ( $10 \mathrm{nM}$, 10 min pretreatment), $1 \mathrm{nM}$ NGF is no longer able to prolong the APD of this same neuron.
NGF-induced release of endogenous adenosine from PC12 cells has been shown to mediate previously reported NGF-induced increases in cAMP by activating Gs-coupled adenosine receptors on these cells (Race and Wagner, 1985). In the presence of adenosine deaminase, NGF failed to increase cAMP in PC12 cells. Application of the adenosine analog, 2-chloro-adenosine to rat DRG neurons in culture has been shown to enhance forskolin-stimulated adenylate cyclase activity, presumably by activating Gs-coupled adenosine $A_{2}$ receptors on these cells (Dolphin et al., 1986) and preliminary tests indicate that adenosine elicits dose-dependent prolongation of the APD of mouse DRG neurons (Shen and Crain, unpublished observations). However, acute application of NGF (0.1 nM) to DRG neurons in the presence of similar concentrations of adenosine deaminase $(1 \mathrm{U} / \mathrm{ml})$ still prolonged the APD by $25-100 \%$ in four of five cells. Therefore, NGF-induced APD prolongation in DRG neurons does not appear to involve release of endogenous adenosine.

Treatment of DRG neurons with cholera toxin $A$ or B subunit blocks $N G F$-induced opioid-mediated APD prolongation. Further evidence consonant with mediation of NGF-induced APD prolongation by secondarily activated excitatory opioid receptors was obtained by pretreating the cells with cholera toxin-A subunit (CTX-A) and cholera toxin-B subunit (CTX-B). We previously showed that APD prolongation elicited in DRG neurons by application of low $(<\mathrm{nM})$ concentrations of exogenous opioid agonists could be prevented by pretreatment with CTX-A (which interfered with Gs coupling of these excitatory opioid receptors to adenylate cyclase: Shen and Crain, 1990a) or with
CTX-B (which interfered with GM1 ganglioside regulation of these receptors: Shen and Crain, 1990b; Shen et al., 1991). In the present study, pretreatment of DRG neurons with CTX-A $(0.1 \mu \mathrm{g} / \mathrm{ml} ;>15 \mathrm{~min})$ blocked NGF-induced APD prolongation (12 of 12 cells; Fig. $3 A$ ), just as it blocks exogenous opioidinduced excitatory effects (Shen and Crain, 1990a). Similarly, pretreatment of DRG neurons with CTX-B $(0.1 \mu \mathrm{g} / \mathrm{ml} ;>15$ min) also blocked NGF-induced prolongation (six of six cells; Fig. $3 B$ ), just as it blocks exogenous opioid-induced excitatory effects (Shen and Crain, 1990b). These blocking effects of CIX-A and CTX-B were reversible after $>1 \mathrm{hr}$ washout in BSS; NGF could then prolong the APD of other DRG ncurons in the same explant.

GMI ganglioside restores $N G F$-induced APD prolongation in $D R G$ neurons after blockade by anti-NGFR treatment. We previously showed that brief treatment of DRG neurons with GM1 ganglioside markedly reduced the threshold concentration of dynorphin $\mathrm{A}(1-13)$ and morphine required to prolong the APD from $1 \mathrm{nM}$ down to $1 \mathrm{fM}$ (Shen et al., 1991). In the present study, similar treatment of DRG neurons with $1 \mu \mathrm{M}$ GM1 ganglioside after blocking NGF-induced APD prolongation with anti-NGFR $(0.5-5 \mu \mathrm{g} / \mathrm{ml})$ resulted in rapid restoration of NGF-induced excitatory effects. These results can be accounted for by the increased efficacy of GM1-sensitized excitatory opioid receptors in responding to the much lower quantities of opioids that may be released from anti-NGFR-treated cells. However, our data do not preclude direct GM1 ganglioside enhancement of NGFinduced release of opioids from DRG neurons that werc incompletely blocked by anti-NGFR. 
A

A

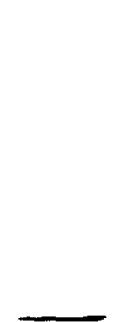

A

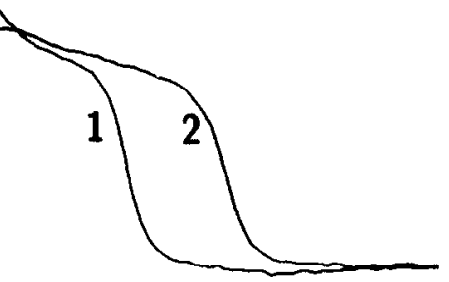

1. BSS

2. NGF $0.1 n M$

3. CTX-A $0.1 \mathrm{ug} / \mathrm{ml}$

4. CTX-A + NGF 0.1nM

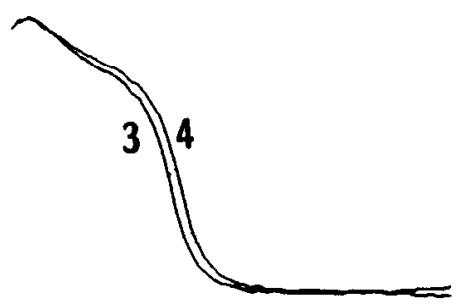

B

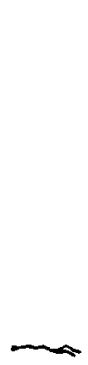

3. CTX-B $0.1 \mathrm{ug} / \mathrm{ml}$

4. CTX-B + NGF 0.1nM

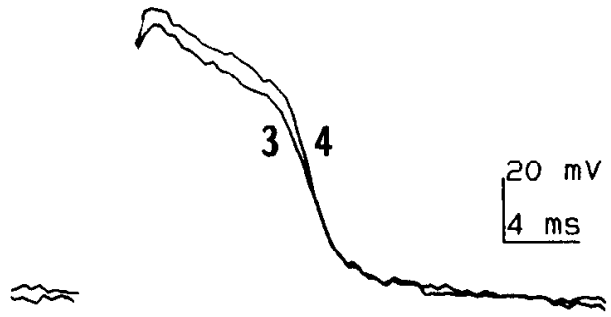

Figure 3. Pretreatment of DRG neurons with cholera toxin A or B subunit blocks NGF-induced opioid-mediated APD prolongation by interfering with Gs-coupling of excitatory opioid receptors to adenylate cyclase or by interfering with GM1 ganglioside regulation of these receptors, respectively. $A_{l, 2}$, APD of a DRG neuron is prolonged by $0.1 \mathrm{nM}$ NGF. $A_{3}$, After BSS rinse and introduction of $0.1 \mu \mathrm{g} / \mathrm{ml}$ CTX-A, APD shortens and is stably maintained ( $\sim 7 \mathrm{~min})$ prior to additional test. $A_{4}$, Application of $0.1 \mathrm{nM}$ NGF in the presence of CTX-A is no longer effective in prolonging the APD. $B_{1,2}$, APD of another DRG neuron is prolonged by $0.1 \mathrm{nM} \mathrm{NGF.} B_{3}$, After BSS rinse and introduction of $0.1 \mu \mathrm{g} / \mathrm{ml}$ CTX-B, APD shortens and is then stably maintained $(\sim 10 \mathrm{~min})$ prior to additional test. $B_{4}$, Application of $0.1 \mathrm{nM} \mathrm{NGF}$ in the presence of CIX-B is no longer able to prolong the APD of this neuron. (These blocking effects of CTX-A and CTX-B were reversible after >1 hr washout in BSS; NGF could then prolong the APD of other DRG neurons in the same explant.)

The kinase inhibitor $K-252 a$ does not interfere with $N G F$ induced APD prolongation. The kinase inhibitor K-252a is known to inhibit selectively many of the effects of NGF on DRG neurons (Matsuda and Fukada, 1988; Doherty and Walsh, 1989) and PC12 cells (Koizumi et al., 1988; Lazarovici et al., 1989; Ferrari et al., 1992). Tests were therefore carried out to determine if this agent might interfere with NGF-induced excitatory effects in DRG neurons. Long-term treatment with K-252a was selected since this inhibitor required at least $30 \mathrm{~min}$ pretreatment (at $0.2 \mu \mathrm{M}$ ) in order to penetrate PC1 2 cells effectively and block NGF-mediated increase in cytosolic $\mathrm{Ca}^{2+}$ (Lazarovici et al., 1989). However, no significant attenuation of NGF-induced APD prolongation was observed after pretreatment with $0.2 \mu \mathrm{M}$ $\mathrm{K}-252 \mathrm{a}$ for periods of $0.5-3 \mathrm{hr}$ acutely or 3-6 d chronically in culture ( 9 of 11 cells after acute treatment and 11 of 15 cells after chronic exposure).

\section{Discussion}

Mediation of NGF-induced APD prolongation in DRG neurons by sequential activation of NGF receptors and excitatory opioid receptors. The present study demonstrates that acute application of low (0.1 pM-nM) concentrations of NGF to DRG-cord explants can rapidly prolong the APD of a major subset $(\sim 80$ $90 \%$ ) of opioid-sensitive DRG neurons in these cultures. These NGF-induced excitatory effects are blocked by pretreatment of the DRG neurons with monoclonal antibodies to rodent NGF receptors. They are also prevented by the opioid receptor an- tagonist naloxone. On the other hand, anti-NGF receptor antibody treatment did not block APD prolongation elicited by exogenous opioids. These results suggest that NGF may directly stimulate the release of endogenous opioid from DRG neurons and that prolongation of the APD occurs secondarily by activation of high-affinity excitatory opioid receptor functions on these same or nearby cells. Our data do not preclude, however, the possibility that small amounts of opioid may be tonically released from DRG neurons that do not reach threshold levels for evoking excitatory opioid receptor-mediated APD prolongation unless their effects are enhanced by a synergistic NGFinduced stimulatory effect on the Gs-coupled opioid second messenger system.

The effectiveness of $0.1-1$ pM concentrations of NGF in prolonging the APD of about $80 \%$ of the DRG neurons tested in the present study is consonant with evidence that $\sim 2$ pM NGF is requircd for half-maximal stimulation of neurite outgrowth or for cell survival in assays of chick embryo DRG neurons in culture (Sutter et al., 1979; Meakin and Shooter, 1992). The high-affinity NGF receptors ( $\mathrm{pl} 40^{\text {trkA }}, K_{d}=10^{-11} \mathrm{M}$ ) have been shown to mediate the major biological responses to NGF (Kaplan et al., 1991; Hempstead et al., 1991; Weskamp and Reichardt, 1991; Meakin and Shooter, 1992). Although no biological responses have been observed to be mediated solely by low-affinity NGF receptors (p75 NGFR,$K_{d}=10^{-9} \mathrm{M}$ ) (Hempstead et al., 1991), these receptors are somehow involved in regulating NGF-induced APD prolongation in DRG neurons because the 
anti-NGFR (192-IgG) that blocks these excitatory effects is directed against the low-affinity $\mathrm{p} 75^{\mathrm{NGFR}}$ (see below).

Role of "low-affinity" $p 75$ NGF receptors in mediating NGFinduced APD prolongation. The present study shows that monoclonal antibodies to rat NGF receptors (192-IgG) that bind to "low-affinity" p 75 NGF receptors (Chandler et al., 1984; Weskamp and Reichardt, 1991) block NGF-induced APD prolongation of DRG neurons. These results are consonant with evidence that this antibody markedly decreases NGF-stimulated neuritic outgrowth from PC12 cells (Chandler et al., 1984) and NGF-stimulated elevation of c-fos mRNA in PC12 cells (Milbrandt, 1986). Furthermore, injection of $192-\operatorname{IgG}$ into fetal rats results in destruction of DRG and sympathetic neurons (Johnson et al., 1989). Affinity cross-linking and gene transfer experiments support a model in which the low-affinity $\mathrm{p} 75^{\mathrm{NGFR}}$ and high-affinity p $140^{\text {rkA }}$ receptors participate in the formation of the high-affinity NGF receptor complex that mediates transmembrane signaling (Berg et al., 1991; Hempstead et al., 1991; Meakin and Shooter, 1991; Weskamp and Reichardt, 1991; Yan et al., 1991; see also Green and Greene, 1986; Levi and Alema, 1991). This model may account for the blocking action of antiNGFR (192-IgG) on NGF-induced APD prolongation in DRG neurons and other biological effects noted above.

Possible NGF-induced release of opioids from DRG neurons that activate $\kappa$-excitatory opioid receptor functions. NGF-induced prolongation of the APD is blocked by the specific $\kappa$-opioid receptor antagonist, nor-binaltorphimine, whereas the specific $\mu$ - and $\delta$-opioid receptor antagonists, $\beta$-funaltrexamine and naltrindole were ineffective. These pharmacologic analyses suggest that NGF may stimulate the release of an opioid that selectively activates $\kappa$ excitatory opioid receptor functions. Our electrophysiologic results are remarkably consonant with radioimmunological and immunohistochemical studies demonstrating that significant concentrations of opioid peptides, especially the $\kappa$-opioid, dynorphin, are present in many sensory ganglion neurons (Botticelli et al., 1981; Chalazonitis et al., 1984), both in perikarya (Sweetnam et al., 1982, 1986; Weihe et al., 1985, 1988a,b) as well as in axons, dorsal roots, and peripheral terminals (Weihe et al., 1985; Basbaum et al., 1986). Interestingly, previous studies have shown that systemically applied NGF induced an enhanced secretion of $\beta$-endorphin, $\mathrm{ACTH}$, and corticosterone in vivo (Otten, 1984).

Sensory neurons have been shown to release substance $\mathbf{P}$ in response to noxious stimuli in vivo (Jessell and Iversen, 1977; Helme et al., 1986; Duggan et al., 1987) and during electrical, high $\mathrm{K}^{+}$- or $\mathrm{PGE}_{2}$-stimulation in culture (Mudge et al., 1979; Holz et al., 1988; Nicol et al., 1992). However, no evidence of the release of opioids from sensory DRG neurons has been reported. In order to obtain more direct evidence that NGFinduced APD prolongation is mediated by NGF-stimulated release of opioids, we have tested the perfusate collected from DRG-cord explants after exposure to NGF ( $0.1 \mathrm{nM}, 5 \mathrm{~min})$. Preliminary tests indicated that this perfusate could, indeed, prolong the APD of anti-NGFR-treated DRG neurons. These data provide further support for our hypothesis, but more systematic electrophysiologic and biochemical assays of the perfusates from NGF-treated DRG neurons are required to determine the quantities and specific molecular moieties of opioids that may be released from these DRG cells.

$D R G$ neurons as a model system for in vitro studies of primary afferent nociceptor functions. As noted above, $80-90 \%$ of the DRG neurons in our long-term DRG-cord explant cultures gen- erate a relatively prolonged APD with a characteristic "hump" on the falling phase of the AP. This hump results from the delayed onset of a voltage-dependent $\mathrm{Ca}^{2+}$ current following the $\mathrm{Na}^{+}$spike that can be markedly shortened or prolonged in duration by specific opioid treatments (see introductory remarks; Mudge et al., 1979; Wer7. and Macdonald, 1983; Chalazonitis and Crain, 1986; Shen and Crain, 1989, 1994). The prolonged APD + hump response of some of the DRG neurons in longterm culture may be due simply to their maintenance in vitro of this type of immature action potential mechanism (Scott and Edwards, 1980) that is characteristic of most rodent DRG cells at birth but is converted to a short APD without hump in large A-type neurons, but not small C-type cells, during maturation in vivo (Yoshida et al., 1978; Yoshida and Matsuda, 1979; Fulton, 1987) and in long-term culture (Matsuda et al., 1978; see also Chalazonitis and Crain, 1986). On the other hand, the prolonged APD + hump response has been shown to be a characteristic property of nociceptive DRG neurons even after maturation in the adult rat (Ritter and Mendell, 1992). This raises the possibility that the large population of small- and mediumsized DRG neurons (10-30 $\mu \mathrm{m}$ in diameter) that continue to show similar prolonged APD + hump responses and opioid responsiveness after many weeks of maturation in long-term culture may provide a useful in vitro model system for analyses of primary afferent nociceptor functions in vivo.

The maturation of these DRG neurons in long-term organotypic explant cultures is evidenced by their progressive development of high levels of opioid receptors in the perikaryal and neuritic outgrowth regions during the first few weeks in vitro (Hiller et al., 1978) and their ability to develop functional opioidsensitive synaptic networks with spinal cord neurons in the dorsal-horn regions of the explants (Crain and Peterson, 1974, 1982; Crain, 1976, 1983). DRG-evoked dorsal horn synaptic network responses in these explants are selectively attenuated by specific opioid agonists at concentrations that correlate well with their analgesic potency in vivo (Crain et al., 1977, 1978, 1984). Furthermore, the much greater potency of etorphine vs morphine in shortening the APD of the DRG neurons in these explants (Shen and Crain, 1994) correlates remarkably well with the 1000-fold greater analgesic potency of etorphine in vivo. These opioid-sensitive properties of DRG neurons in culture are, therefore, quite consonant with the selective inhibitory effects of opioids on nociceptive, but not proprioceptive, primary afferent neurons in vivo.

The excitatory effects of bradykinin, capsaicin, and prostaglandin $E_{2}$ (Baccaglini and Hogan, 1983; Pitchford and Levine, 1991; Nicol et al., 1992) on many DRG neurons in culture provide additional evidence indicating maintenance of nociceptor functions in vitro. Interestingly, capsaicin, which selectively activates nociceptive DRG neurons in vivo and in culture (Pitchford and Levine, 1991), has recently been shown to attenuate the anti-nociceptive effects of systemic morphine by releasing excitatory amounts of dynorphin in the spinal cord following intrathecal injection of low doses of capsaicin in adult mice (Arts et al., 1992). This selective excitatory effect of capsaicin-stimulated dynorphin on nociceptive input into the spinal cord, which is blocked by naloxone and nor-binaltorphimine, strengthens our hypothesis that NGF elicits excitatory $k$-opioidmediated effects on nociceptive types of DRG neurons (see also anti-analgesic effects of dynorphin by Fujimoto and Rady, 1989, noted below).

Ritter and Mendell (1992) showed that chronic treatment of 
newborn rats with NGF for 5 weeks in vivo resulted in a selective prolongation of the APD of nociceptive, but not proprioceptive, DRG neurons (identified by the characteristic long APD + hump criterion noted above). The mechanism of action of NGF in eliciting APD prolongation of nociceptive DRG neurons after chronic treatment in vivo is probably more complex than that mediating the rapid NGF-induced APD prolongation observed in cultured DRG neurons in the present study (see below). Nevertheless, these correlative data add further support to the view that the NGF-sensitive population of DRG neurons in our cultures show significant functional similarities to NGF-sensitive nociceptive DRG neurons in vivo.

The preponderance of DRG neurons that are sensitive to NGF and opioids in our long-term explant cultures may be due to preferential rescue of small, nociceptive DRG cells at immature stages, when they are dependent for survival on NGF (LeviMontalcini, 1965), by NGF treatment during the first week in culture (Crain and Peterson, 1974, 1984; Crain, 1976; see Materials and Methods). These in vitro results are similar to the selective rescue of small-diameter nociceptive DRG neurons, but not large proprioceptive neurons, by injections of NGF in newborn rats after nerve section (Miyata et al., 1986). In the absence of NGF treatment, $>90 \%$ of the fetal DRG neurons degenerate during the first few days in culture, resembling the selective loss of $80-90 \%$ of small nociceptive-type DRG cells with unmyelinated axons following NGF-deprivation in utero (Johnson et al., 1980, 1986; Goedert et al., 1984; Otten, 1984). These factors may account for the higher proportion of NGFsensitive DRG neurons, $\sim 80-90 \%$ in our long-term cultures, in contrast to the distribution of high-affinity NGF receptors on $40-45 \%$ of adult rat DRG neurons (Richardson et al., 1986; Verge et al., 1989b). The relatively sparse population of large DRG neurons that generate short APDs in our long-term cultures may be due to their preferential dependence on skin and muscle target tissues (Levi-Montalcini, 1966), which are absent in these cultures or to inadequate levels of growth factors other than NGF that may be required by proprioceptive types of DRG neurons.

Relevance of $N G F$-induced $A P D$ prolongation in $D R G$ neurons in culture to $N G F$-induced hyperalgesia in vivo. Our electrophysiologic evidence of rapid NGF-induced opioid-mediated excitatory effects on "nociceptive"-like DRG neurons in culture may clarify cellular mechanisms underlying the hyperalgesia observed after intravenous administration of NGF in adult mice (Levi-Montalcini et al., 1990) and the heat hyperalgesia that has recently been shown to occur within $10 \mathrm{~min}$ after injection of NGF ( $1 \mu \mathrm{g} / \mathrm{gm}$, i.p.) in adult rats (Lewin et al., 1993). The relevance of opioid-induced excitatory prolongation of the APD of DRG neurons in culture to hyperalgesia in vivo is further suggested by studies with an animal model of persistent pain in arthritic rats where "exceedingly low doses of morphine. . . elicit a naloxone-reversible paradoxical hyperalgesia" (Kayser et al., 1987). In addition, evidence has been reported of naloxonereversible hyperalgesia mediated by activation of $k$-opioid receptors on neurons in the brainstem and cervical spinal cord (Wu et al., 1983; Hamann and Martin, 1992; Parvini et al., 1993). These hyperalgesic effects may be due in part, to enhanced release of substance $P$, which has been shown to occur following activation of $k$-opioid excitatory receptors on rat trigeminal neurons (Suarez-Roca and Maixner, 1993). The excitatory effect of low concentrations of dynorphin and other $\kappa$-opioids on DRG neurons is also consonant with in vivo studies demonstrating that extremely low intrathecal doses of dynorphin $(\sim 0.05 \mathrm{fmol})$ in adult mice can attenuate the anti-nociceptive effects of systemic morphine (Fujimoto and Rady, 1989). This anti-analgesic excilatory effect of dynorphin can be blocked not only by the opioid receptor antagonists naloxone and norbinaltorphimine, but also by intrathecal administration of cholera toxin (Fujimoto et al., 1992; Arts et al., 1993).

If NGF-induced hyperalgesia in vivo is indeed mediated by activation of $\kappa$ excitatory opioid receptors on nociceptive neurons and can be prevented simply by coadministration of an opioid antagonist, the results of the present study may help to eliminate this undesirable side effect during clinical use of exogenous NGF for treatment of taxol-induced (Apfel et al., 1991) and diabetic (Apfel et al., 1992) sensory neuropathies as well as other neurologic disorders (Marz, 1990). Stimulated by our evidence that NGF-induced excitatory effects on DRG neurons are mediated by activation of $\kappa$-opioid receptors, Apfel et al. (1993) have shown that NGF-induced hyperalgesia in adult mice and rats can indeed be prevented not only by naloxone but also by nor-binaltorphimine, precisely as predicted by the present tissue culture study.

NGF-induced prolongation of the APD in the perikarya of "nociceptive"-like DRG neurons in culture provides a mechanism that may account for NGF-induced increases in $\mathrm{Ca}^{2+}$ influx and excitability at peripheral as well as central terminals of primary afferent nociceptors in vivo. Lewin et al (1993) have suggested that it is unlikely that NGF could gain direct access to the CNS when administered systemically in adult animals, so that the rapid onset of NGF-induced heat hyperalgesia is probably due to sensitization of the receptors of peripheral unmyelinated afferents to heat. This is consonant with evidence that NGF receptors (Verge et al., 1989a; Di Stefano et al., 1992) as well as opioid receptors (Hiller et al., 1978; Fields et al., 1980; Basbaum and Levine, 1991; Levine et al., 1993) are distributed on peripheral as well as central branches of DRG neurons.

The present in vitro study may also provide insight into a possible physiologic role for dynorphin in sensory neurons in mediating NGF-induced nociceptive or "alerting" signals into the CNS during neural injury (Bakhit et al., 1991; MartinezMurillo et al., 1993) or other conditions where NGF levels are acutely elevated, for example, aggressive and defensive behavior (Aloe et al., 1986; Levi-Montalcini et al., 1990).

Blockade of NGF-induced APD prolongation by $C T X-A$ or $C T X-B$ and enhancement by GMI ganglioside may be due to effects on opioid-rather than $N G F$-receptor functions. The blockade of NGF-induced prolongation of the APD of DRG neurons by low concentrations of CTX-A as well as CTX-B initially suggested possible Gs-coupling and GM1 ganglioside regulation of the NGF receptors mediating these excitatory effects. However, it is more likely that these results are due to the blocking effects of CTX-A and CTX-B on the secondarily activated excitatory opioid receptor functions, similar to the actions of these toxin components in preventing exogenous opioid-induced APD prolongation (Shen and Crain, 1990a,b). Furthermore, no evidence of direct NGF receptor coupling to Gs or Gi has been detected (Levi and Alema, 1991).

Although the kinase inhibitor K-252a selectively inhibits many of the effects of NGF on PC12 cells (Koizumi et al., 1988), it did not antagonize NGF-induced release of dopamine and norepinephrine from these cells and, in fact, mimicked this action of NGF on PC1 2 cells (Nikodijevic et al., 1990). Furthermore, although K-252a blocked NGF-induced survival of chick em- 
bryo sympathetic neurons in culture, it did not interfere with NGF-mediated survival of chick embryo DRG neurons grown under the same culture conditions (Borasio, 1990). Therefore, the absence of blocking effects by K-252a on NGF-induced APD prolongation must be interpreted with caution. If $\mathrm{K}-252 \mathrm{a}$ does, in fact, block the rapid NGF-induced increase in intracellular calcium in DRG neurons as occurs in PCI 2 cells (Lazarovici et al., 1989), these results suggest that NGF-induced opioid release may not require a large increase in intracellular $\mathrm{Ca}^{2+}$ concentration (as also observed during studies of NGF-induced histamine release in mast cells: Mazurek et al., 1986). Furthermore, since introduction of exogenous ganglioside can overcome the inhibitory effects of K-252a on NGF-induced neurite outgrowth in PC1 2 cells (Ferrari et al., 1992), perhaps the endogenous levels of ganglioside in these cells may also play a role in determining their sensitivity to $\mathrm{K}-252 \mathrm{a}$ inhibition of transmitter release. In the present study, however, elevation of GM1 ganglioside may restore NGF-induced APD prolongation in antiNGFR-treated DRG neurons by greatly increasing the efficacy of opioid excitatory receptor functions (Shen et al., 1991) elicited by activation of a small population of unblocked NGF receptors, rather than by a direct action of GM1 on NGF receptors.

Alterations of the APD of DRG neurons after chronic treatment with $N G F$. As noted above, chronic exposure of mature DRG neurons in organotypic explant cultures to $\mathrm{NGF}$ for $>2 \mathrm{~d}$ results in shortening of the APD (Chalazonitis et al., 1987). The mechanism underlying this long-term effect of NGF on the AP of DRG neurons is unknown. Perhaps it is due to a compensatory metabolic process that develops in these DRG cells that counteracts the initial NGF-induced excitatory APD prolongation observed in the present study. This shortening of the APD of DRG neurons during a $>2 \mathrm{~d}$ exposure to NGF occurs in populations of cells that have become stabilized after 3-4 weeks in control culture medium and show no significant morphological alterations during the NGF test period. On the other hand, chronic injections of newborn rats with NGF for 5 weeks resulted in a small but significant increase in the APD of nociceptive DRG neurons (Ritter and Mendell, 1992). However, this long-term effect may be due to complex developmental alterations in the properties of neonatal DRG cells in vivo (Ritter et al., 1993), involving mechanisms that may be quite different than those mediating the APD modulation elicited by NGF within a few minutes or a few days after application to relatively mature DRG neurons in culture.

Concluding remarks. The experimental paradigm used in the present study provides a sensitive electrophysiologic tissue culture model system for analyses of some of the rapid excitatory effects of NGF on primary afferent nociceptive neurons that can occur within a few min after application of low concentrations of NGF. This technique may facilitate studies of physiological factors that modulate the efficacy of NGF receptor-mediated functions and may provide a useful method for analyses of possible G-protein-linked signal transduction mechanisms (other than Gs and Gi) that may be associated with NGF receptors (Meakin and Shooter, 1992).

\section{References}

Aloe L, Alleva E, Bohm A, Levi-Montalcini R (1986) Aggressive behavior induces release of nerve growth factor from mouse salivary gland into the bloodstream. Proc Natl Acad Sci USA 83:6184-6187.

Apfel SC, Lipton RB, Arezzo JC, Kessler JA (1991) Nerve growth factor prevents toxic neuropathy in mice. Ann Neurol 29:87-90.

Apfel SC, Arezzo JC, Brownlee M, Moran M, Barnecott PK, Kessler
JA (1992) Trophic factor prevention of diabetic neuropathy in a streptozocin rat model. Soc Neurosci Abstr 18:776.

Apfel SC, Newell ME, Kessler JA (1993) Opioid antagonists block NGF induced thermal hyperalgesia. Soc Neurosci Abstr 19:665.

Arts KS, Fujimoto JM, Tseng LF (1992) Involvement of dynorphin $A$ and not substance $P$ in the spinal antianalgesic action of capsaicin against morphine-induced antinociception in mice. J Pharmacol Exp Ther 261:643-651.

Arts KS, Fujimoto JM, Crain SM (1993) Inhibition of the antianalgesic action of dynorphin $A$ in mice by cholera toxin. Pharmacol Biochem Behav 46:623-629.

Baccaglini PL, Hogan PG (1983) Some rat sensory neurons in culture express characteristics of differentiated pain sensory cells. Proc Natl Acad Sci USA 80:594-598.

Bakhit C, Armanini M, Bennett GL, Wong WLT, Hansen SE, Taylor $R$ (1991) Increase in glia-derived nerve growth factor following destruction of hippocampal neurons. Brain Res 560:76-83.

Basbaum AI, Levine JD (1991) Opiate analgesia: how central is a peripheral target? N Engl J Med 325:1168-1 169

Basbaum AI, Cruz L, Weber E (1986) Immunoreactive dynorphin B in sacral primary afferent fibers of the cat. J Neurosci 6:127-133.

Berg MM, Sternberg DW, Hempstead BL, Chao MV (1991) The lowaffinity p75 nerve growth factor (NGF) receptor mediates NGF-induced tyrosine phosphorylation. Proc Natl Acad Sci IISA 88:71067110 .

Borasio GD (1990) Differential effects of the protein kinase inhibitor $\mathrm{K}-252 \mathrm{a}$ on the in vitro survival of chick embryonic neurons. Ncurosci Lett 108:207-212.

Botticelli LJ, Cox BM, Goldstein A (1981) Immunoreactive dynorphin in mammalian spinal cord and dorsal root ganglia. Proc Natl Acad Sci USA 78:7783-7786.

Bruni A, Bigon E, Boarato E, Mietto L, Leon A, Toffano G (1982) Interaction between NGF and lysophosphatidylserine on rat peritoneal mast cells. FEBS Lett 138:190-192.

Chalazonitis A, Crain SM (1986) Maturation of opioid sensitivity of fetal mouse dorsal root ganglion neuron perikarya in organotypic cultures: regulation by spinal cord. Neuroscience 17:1181-1198

Chalazonitis A, Groth J, Hiller JM, Simon EJ, Crain SM (1984) Development of met-enkephalin immunoreactivity in organotypic explants of fetal mouse spinal cord and attached dorsal root ganglia. Dev Brain Res 12:183-189.

Chalazonitis A, Peterson ER, Crain SM (1987) Nerve growth factor regulates the action potential duration of mature sensory neurons. Proc Nall Acad Sci USA 84:289-293.

Chandler CE, Parsons LM, Hosang M, Shooter EM (1984) A monoclonal antibody modulates the interaction of nerve growth factor with PC12 cell. J Biol Chem 259:6882-6889.

Chen G-G, Chalazonitis A, Shen K-F, Crain SM (1988) Inhibitor of cyclic AMP-dependent protein kinase blocks opioid-induced prolongation of the action potential of mouse sensory ganglion neurons in dissociated cell culture. Brain Res 462:372-377.

Crain SM (1976) Neurophysiologic studies in tissue culture. New York: Raven.

Crain SM (1983) Role of CNS target cues in formation of specific afferent synaptic connections in organotypic cultures. In: Neuroscience approached through cell culture, Vol II (Pfeiffer SE, ed), pp 132. Boca Raton, FL: CRC.

Crain SM (1984) Tissue culture models for analyses of opioid analgesia, tolerance and plasticity. In: NIDA research monograph ADM 84-1330, Mechanisms of tolerance and dependence (Sharp C, ed), pp 260-292. Washington, DC: U.S. GPO.

Crain SM, Peterson ER (1974) Enhanced afferent synaptic function in fetal mouse spinal cord-sensory ganglion explants following NGFinduced ganglion hypertrophy. Brain Res 79:145-152.

Crain SM, Peterson ER (1982) Selective innervation of target regions within fetal mouse spinal cord and medulla explants by isolated dorsal root ganglion in organotypic co-cultures. Dev Brain Res 2:341-362.

Crain SM, Peterson ER (1984) Enhanced dependence of fetal mouse neurons on trophic factors after taxol exposure in organotypic cultures. In: Cellular and molecular biology of neuronal development (Black IB, ed), pp 177-200. New York: Plenum.

Crain SM, Shen K-F (1990) Opioids can evoke direct receptor-mediated excitatory effects on sensory neurons. Trends Physiol Sci 11: $77-81$.

Crain SM, Shen K-F (1992a) After chronic opioid exposure sensory 
neurons become supersensitive to the excitatory effects of opioid agonists and antagonists as occurs after acute elevation of GM1 ganglioside. Brain Res 575:13-24.

Crain SM, Shen K-F (1992b) After GM1 ganglioside treatment of sensory neurons naloxone paradoxically prolongs the action potential but still antagonizes opioid inhibition. J Pharmacol Exp Ther 260: 182-186.

Crain SM, Peterson ER, Crain B, Simon EJ (1977) Selective opiate depression of sensory-evoked synaptic networks in dorsal-horn region of spinal cord cultures. Brain Res 133:162-166.

Crain SM, Crain B, Peterson ER, Simon (1978) Selective depression by opioid peptides of sensory-evoked dorsal-horn network responses in organized spinal cord cultures. Brain Res 157:196-201.

Cruciani RA, Dvorkin B, Morris SA, Crain SM, Makman MH (1993) Direct coupling of opioid receptors to both $\mathrm{Gs}$ and $\mathrm{Gi}$ proteins in F-11 neuroblastoma $\times$ sensory neuron hybrid cells. Proc Natl Acad Sci USA 90:3019-3023.

DiStefano PS, Friedman B, Radziewjewski C, Alexander C, Boland P, Schick CM, Lindsay RM, Wiegand SJ (1992) The neurotrophins BDNF, NT-3 and NGF display distinct patterns of retrograde axonal transport in peripheral and central neurons. Neuron 8:983-993.

Doherty P, Walsh FS (1989) K-252a specifically inhibits the survival and morphological differentiation of NGF-dependent neurons in primary cultures of human dorsal root ganglia. Neurosci Lett 96:1-6.

Dolphin AC, Forda SR, Scott RH (1986) Calcium-dependent currents in cultured rat dorsal root ganglion neurons are inhibited by an adenosine analogue. J Physiol (Lond) 373:47-61.

Duggan AW, Morton CR, Zhao ZQ, Hendry IA (1987) Noxious heating of the skin releases immunoreactive substance $P$ in the substantia gelatinosa of the cat: a study with antibody microprobes. Brain Res 403:345-349.

Fan S-F, Shen K-F, Crain SM (1991) Opioids at low concentration decrease openings of $\mathrm{K}^{+}$channels in sensory ganglion neurons. Brain Res 558:166-170.

Ferrari G, Fabris M, Fiori MG, Gabellini N, Volonte C (1992) Gangliosides prevent the inhibition by $\mathrm{K}-252 \mathrm{a}$ of $\mathrm{NGF}$ responses in $\mathrm{PC} 12$ cells. Develop Brain Res 65:35-42.

Fields HL, Emson PC, Leigh BK, Gilbert RFT, Iversen LL (1980) Multiple opiate receptor sites on primary afferent fibers. Nature 284 351-353.

Fujimoto JM, Rady JJ (1989) Intracerebroventricular physostigmineinduced analgesia: enhancement by naltrexone, beta-funaltrexamine and nor-binaltorphimine and antagonism by dynorphin $\mathrm{A}(1-17)$. J Pharmacol Exp Ther 251:1045-1052.

Fujimoto JM, Arts KS, Rady JJ, Tseng LF (1990) Spinal dynorphin A(1-17): possible mediation of antianalgesic actions. Neuropharmacol 29:609-617.

Fujimoto JM, Arts KS, Crain SM (1992) Cholera toxin (CTX) diminishes the antianalgesic action of spinal dynorphin $\mathrm{A}$ in mice. FASEB J 6:A1302.

Fulton BP (1987) Postnatal changes in conduction velocity and soma action potential parameters of rat dorsal root ganglion neurones. Neurosci Lett 73:125-130.

Goedert M, Otten U, Hunt SP, Bond A, Chapman D, Schlumpf M, Lichtensteiger W (1984) Biochemical and anatomical effects of antibodies against nerve growth factor on developing rat sensory ganglion. Proc Natl Acad Sci USA 81:1580-1584.

Green SH, Greene LA (1986) A single $M_{r} 103,000^{125} \mathrm{I}-\beta$ nerve growth factor-affinity-labeled species represents both the low and high affinity forms of the nerve growth factor receptor. J Biol Chem 261:1531615326.

Greene LA (1984) The importance of both early and delayed responses in the biological actions of nerve growth factor. Trends Neurol Sci 7:91-94.

Greene LA, Shooter EM (1980) The nerve growth factor: biochemistry, synthesis and mechanism of action. Annu Rev Neurosci 3:353-402.

Hamann SR, Martin WR (1992) Opioid and nicotinic analgesic and hyperalgesic loci in the rat brain stem. J Pharmacol Exp Ther 261: 707-715.

Helme RD, Koschorke GM, Zimmermann M (1986) Immunoreactive substance $P$ release from skin nerves in the rat by noxious thermal stimulation. Neurosci Lett 63:295-299.

Hempstead BL, Martin-Zanca D, Kaplan DR, Parada LF, Chao MV (1991) High-affinity NGF binding requires coexpression of the trk proto-oncogene and the low-affinity NGF receptor. Nature 350:678683.
Hiller JM, Simon EJ, Crain SM, Peterson ER (1978) Opiate receptors in cultures of fetal mouse dorsal root ganglion (DRG) and spinal cord: predominance in DRG neurites. Brain Res 145:396-400.

Holz GG IV, Dunlap K, Kream RM (1988) Characterization of the electrically evoked release of substance $P$ from dorsal root ganglion neurons: methods and dihydropyridine sensitivity. J Neurosci 8:463471.

Jessell TM, Iversen LL (1977) Opiate analgesics inhibit substance P release from rat trigeminal nucleus. Nature 268:549-551.

Johnson EM Jr, Gorin PD, Brandeis LD, Pearson J (1980) Dorsal root ganglion neurons are destroyed by exposure in utero to maternal antibody to nerve growth factor. Science 210:916-918.

Johnson EM Jr, Rich KM, Yip HK (1986) The role of NGF in sensory neurons in vivo. Trends Neurosci 9:3-37.

Johnson EM Jr, Osborne PA, Taniuchi M (1989) Destruction of sympathetic and sensory neurons in the developing rat by a monoclonal antibody against the nerve growth factor (NGF) receptor. Brain Res 478:166-170.

Kaplan DR, Hempstead BL, Martin-Zanca D, Chao MV, Parada LF (1991) The trk proto-oncogene product: a signal transducing receptor for nerve growth factor. Science 252:554-558.

Kayser V, Besson JM, Guilbaud G (1987) Paradoxical hyperalgesic effect of exceedingly low doses of systemic morphine in an animal model of persistent pain (Freund's adjuvant-induced arthritis rats). Brain Res 414:155-157.

Koizumi S, Contreras ML, Matsuda Y, Hama T, Lazarovici P, Guroff $G$ (1988) K252a: a specific inhibitor of the action of NGF on $\mathrm{PCl} 2$ cells. J Neurosci 8:715-721.

Lavarovici P, Levi B-Z, Lelkes PI, Koizumi S, Fujita K, Matsuda, Y, Ozato K, Guroff G (1989) K-252a inhibits the increase in c-fos transcription and the increase in intracellular calcium produced by nerve growth factor in PC12 cells. J Neurosci Res 23:1-8.

Levi A, Alema S (1991) The mechanism of action of nerve growth factor. Annu Rev Pharmacol Toxicol 31:205-228.

Levi-Montalcini R (1965) Morphological and metabolic effects of the nerve growth factor. Arch Biol (Liege) 76:387-417.

Levi-Montalcini R (1966) The nerve growth factor, its mode of action on sensory and sympathetic nerve cells. Harvey Lect 60:217-259.

Levi-Montalcini R, Aloe L, Alleva E (1990) A role for NGF in neurons, endocrine and immune systems. Prog Neuroendocr Immunol 3:110.

Levine JD, Fields HL, Basbaum AI (1993) Peptides and the primary afferent nociceptor. J Neurosci 13:2273-2286.

Lewin GR, Ritter AM, Mendell LM (1993) Nerve growth factorinduced hyperalgesia in the neonatal and adult rat. $\mathrm{J}$ Neurosci 13 : 2136-2148.

Makman MH, Dvorkin B, Crain SM (1994) Opioid receptor-mediated stimulation of adenylate cyclase activity of dorsal root ganglion-spinal cord explants by dynorphin and levorphanol. Brain Res, in press.

Martinez-Murillo R, Caro L, Nieto-Sampedro M (1993) Lesion-induced expression of low-affinity nerve growth factor receptor-immunoreactive protein in Purkinje cells of the adult rat. Neuroscience 52:587-593.

Marz J (1990) NGF and Alzheimer's: hopes and fears. Science 247: 408-410.

Matsuda Y, Fukuda J (1988) Inhibition by K-252a, a new inhibitor of protein kinase, of nerve growth factor-induced neurite outgrowth of chick embryo dorsal root ganglion cells. Neurosci Lett 87:11-17.

Matsuda Y, Yoshida S, Yonezawa T (1978) Tetrodotoxin sensitivity and $\mathrm{Ca}$ component of action potentials of mouse dorsal root ganglion cells cultured in vitro. Brain Res 154:69-82.

Mazurek N, Weskamp G, Erne P, Otten U (1986) NGF induces mast cell degranulation without changing in tracellular calcium levels. FEBS Lett 198:315-320.

Meakin SD, Shooter EM (1992) The nerve growth factor family of receptors. Trends Neurol Sci 15:323-331.

Milbrandt J (1986) Nerve growth factor rapidly induces c-fos mRNA in PC12 rat pheochromocytoma cells. Proc Natl Acad Sci USA 83: $4789-4793$.

Miyata Y, Kashihara Y, Homma S, Kuno M (1986) Effects of nerve growth factor on the survival and synaptic function of Ia sensory neurons axotomized in neonatal rats. J Neurosci 6:2012-2018.

Mudge AW, Leeman SE, Fischbach GD (1979) Enkephalin inhibits release of substance $\mathbf{P}$ from sensory neurons in culture and decreases action potential duration. Proc Natl Acad Sci USA 76:526-530.

Nicol GD, Klingberg DK, Vasko MR (1992) Prostaglandin $\mathrm{E}_{2}$ increas- 
es calcium conductance and stimulates release of substance $P$ in avian sensory neurons. J Neurosci 12:1917-1927.

Nikodijevic B, Nikodijevic O, Yu M-YW, Pollard H, Guroff G (1975) The effect of nerve growth factor on cyclic AMP levels in superior cervical ganglia of the rat. Proc Natl Acad Sci USA 72:4769-4771.

Nikodijevic B, Creveling CR, Koizumi S, Guroff G (1990) Nerve growth factor and $\mathrm{K} 252 \mathrm{a}$ increase catecholamine release from $\mathrm{PC} 12$ cells. J Neurosci Res 26:288-295.

Otten $U$ (1984) Nerve growth factor and the peptidergic sensory neurons. Trends Pharmacol Sci 5:307-310.

Parvini S, Hamann SR, Martin WR (1993) Pharmacologic characteristics of a medullary hyperalgesic center. J Pharmacol Exp Ther 265:286-293.

Pitchford S, Levine JD (1991) Prostaglandins sensitize nociceptors in cell culture. Neurosci Lett 132:105-108.

Race HM, Wagner JA (1985) NGF affects cyclic AMP metabolism, but not by directly stimulating adenylate cyclase activity. J Neurochem 44:1588-1592.

Richardson PM, Verge VMK, Riopelle RJ (1986) Distribution of neuronal receptors for nerve growth factor in the rat. J Neurosci 6:2312-2321

Ritter AM, Mendell LM (1992) Somal membrane properties of physiologically identified sensory neurons in the rat: effects of nerve growth factor. J Neurophysiol 68:2033-2041.

Ritter AM, Lewin GR, Mendell LM (1993) Regulation of myelinated nociceptor function by nerve growth factor in neonatal and adult rats. Brain Res Bull 30:245-249.

Schubert D, LaCorbiere M, Whitlock C, Stallcup W (1978) Alterations in the surface properties of cells responsive to NGF. Nature 273:718723.

Scott BS, Edwards BAV (1980) Electric membrane properties of adult mouse DRG neurons and the effect of culture duration. J Neurobiol 11:291-301.

Shen K-F, Crain SM (1989) Dual opioid modulation of the action potential duration of mouse dorsal root ganglion neurons in culture. Brain Res 491:227-242.

Shen K-F, Crain SM (1990a) Cholera toxin-A subunit blocks opioid excitatory effects on sensory neuron action potentials indicating mediation by Gs-linked opioid receptors. Brain Res 525:225-231.

Shen K-F, Crain SM (1990b) Cholera toxin-B subunit blocks excitatory effects of opioids on sensory neuron action potentials indicating that GM 1 ganglioside may regulate Gs-linked opioid receptor functions. Brain Res 531:1-7.

Shen K-F, Crain SM (1993) Nerve growth factor rapidly prolongs the action potential of mature sensory neurons in culture and this effect requires activation of Gs-coupled excitatory kappa opioid receptors on these cells. Soc Neurosci Abstr 19:1153.

Shen K-F, Crain SM (1994) Antagonists at excitatory opioid receptors on sensory neurons in culture increase potency and specificity of opiate analgesics and attenuate development of tolerance/dependence. Brain Res 636:286-297.

Shen K-F, Crain SM, Ledeen RW (1991) Brief treatment of sensory ganglion neurons with GM1 ganglioside enhances the efficacy of opioid excitatory effects on the action potential. Brain Res 559:130-138.

Skaper SD, Bottenstein JE, Varon S (1979) Effects of NGF on cyclic AMP levels in embryonic chick dorsal root ganglia following factor deprivation. Neurochemistry 32:1845-1851.
Suarez-Roca H, Maixner W (1993) Activation of kappa opioid receptors by $\mathrm{U} 50488 \mathrm{H}$ and morphine enhances the release of substance $\mathrm{P}$ from rat trigeminal nucleus slices. J Pharmacol Exp Ther 264:648653.

Sugiyama K, Suzuki Y, Furuta H (1985) Histamine-release induced by $7 \mathrm{~S}$ NGF of mouse submandibular salivary glands. Arch Oral Biol 30:93-95.

Sutter A, Riopelle RJ, Harris-Warrick RM, Shooter EM (1979) Nerve growth factor receptors. J Biol Chem 254:5972-5982.

Sweetnam PM, Neale, JH, Barker JL, Goldstein A (1982) Localization of immunoreactive dynorphin in neurons cultured from spinal cord and dorsal root ganglia. Proc Natl Acad Sci USA 79:6742-6746.

Sweetnam PM, Wrathall JR, Neale JII (1986) Localization of dynorphin gene product-immunoreactivity in neurons from spinal cord and dorsal root ganglia. Neuroscience 18:947-955.

Taniuchi M, Clark HB, Johnson EM Jr (1986) Induction of nerve growth factor receptor in Schwann cells after axotomy. Proc Natl Acad Sci USA 83:4094-4098.

Verge VMK, Riopelle RJ, Richardson PM (1989a) Nerve growth factor receptors on normal and injured sensory neurons. J Neurosci 9:914-922.

Verge VMK, Richardson PM, Benoit R, Riopelle RJ (1989b) Histochemical characterization of sensory neurons with high-affinity receptors for nerve growth factor. J Neurocytol 18:583-591.

Weihe E, Hartschuh W, Weber E (1985) Prodynorphin opioid peptides in small somatosensory primary afferents of guinea pig. Neurosci Lett $58: 347-352$.

Weihe E, Nohr D, Hartschuh W (1988a) Immunohistochemical evidence for a co-transmitter role of opioid peptides in primary sensory neurons. Prog Brain Res 74:189-199.

Weihe E, Nohr D, Gauweiler B, Fink T, Nowak E, Konrad S (1988b) Immunohistochemical evidence for a diversity of opioid coding in peripheral sympathetic, parasympathetic and sensory neurons: a general principle of prejunctional opioid autoinhibition? In: Regulatory role of opioid peptides (Illes P, Farsang C, eds), pp 16-32. Weinheim, Germany: VCH.

Werz MA, Macdonald RL (1983) Opioid peptides with differential affinity for mu- and delta-receptors decrease sensory neuron calciumdependent action potentials. J Pharmacol Exp Ther 227:394-402.

Weskamp G, Reichardt LF (1991) Evidence that biological activity of NGF is mediated through a novel subclass of high affinity receptors. Neuron 6:649-663.

Wu KM, Martin WR, Kamerling SG, Wettstein JG (1983) Possible medullary kappa hyperalgesic mechanism. I. A new potential role for endogenous opioid peptide in pain perception. Life Sci 33:1831-1838.

Yan H, Schlessinger J, Chao MV (1991) Chimeric NGF-EGF receptors define domains responsible for neuronal differentiation. Science 252: 561-563.

Yoshida S, Matsuda Y (1979) Studies on sensory neurons of the mouse with intracellular recording and horseradish peroxidase-injection techniques. J Neurophysiol 42:1134-1145.

Yoshida S, Matsuda Y, Samejima A (1978) Tetrodotoxin-resistant sodium and calcium component of action potentials in dorsal root ganglion cells of the adult mouse. J Neurophysiol 41:1096-1106. 